\title{
HFmrEF: Közepes ejekciós frakciójú szívelégtelenség
}

\section{Nyolczas Noémi}

\author{
Magyar Honvédség Egészségügyi Központ, Kardiológiai Osztály, Budapest \\ Levelezési cím: \\ Dr. Nyolczas Noémi, 1134 Budapest, Róbert Károly krt. 44., e-mail: nyolczasnoemi@gmail.com
}

Az Európai Kardiológus Társaság 2016-ban a csökkent ejekciós frakciójú (HFrEF) és a megtartott ejekciós frakciójú szívelégtelenség (HFpEF) mellett bevezette a közepes ejekciós frakciójú szívelégtelenség (HFmrEF) fogalmát. Az új kategória bevezetésének célja elsősorban az volt, hogy inspirálja e betegcsoport tanulmányozásával foglalkozó kutatásokat. Az elmúlt években az ezirányú vizsgálatok száma megsokszorozódott. Az összefoglaló közlemény áttekintést kíván adni a rendelkezésünkre álló vizsgálati eredmények alapján a HFmrEF epidemiológiájáról, klinikai jellemzőiről, morbiditásáról és mortalitásáról, a kezelési lehetőségekről, a kórkép etiológiai diagnózisának fontosságáról, valamint a hosszú távú követés jelentőségéről.

Kulcsszavak: közepes ejekciós frakciójú szívelégtelenség

\section{HFmrEF - Heart failure with mid-range ejection fraction}

In 2016, the European Society of Cardiology introduced the category of heart failure with mid-range ejection fraction (HFmrEF) besides heart failure with reduced ejection fraction (HFrEF) and heart failure with preserved ejection fraction (HFpEF). The primary aim of the introduction of the new category was to inspire research into studying this group of patients. In recent years, the number of studies assessed HFmrEF was multiplied. This review summarizes what is known about epidemiology, clinical characteristics, morbidity and mortality, therapeutic options, the importance of etiological diagnosis and long-term follow up of HFmrEF patients.

Keywords: heart failure with mid-range ejection fraction

\section{Bevezetés}

Az 1970-es évek végéig tartotta magát az a nézet, hogy szívelégtelensége csak csökkent bal kamrai ejekciós frakciójú (BKEF) betegnek lehet, amikor a betegség hátterében döntően a bal kamra kontraktilitásának zavara áll. Azóta tudjuk, hogy szívelégtelenségre jellemző tünetei, panaszai olyan betegeknek is lehetnek, akiknek a BKEF-je megtartott, elsősorban a bal kamra tágulékonyságának csökkenése, a bal kamra telődésének károsodása miatt.

Ezt követően a következő fontos kérdés az volt, hogy mit nevezünk csökkent ejekciós frakciójú szívelégte- lenségnek (heart failure with reduced ejection fraction - HFrEF), és mit nevezünk megtartott ejekciós frakciójú szívelégtelenségnek (heart failure with preserved ejection fraction). Nyilvánvaló volt, hogy a két szívelégtelenség-kategória nem választható el egymástól egy meghatározott BKEF-érték segítségével. Az első definíció ebben a vonatkozásban 2013-ban, az amerikai kardiológus társaságok (ACC/AHA) által ekkor publikált szívelégtelenség irányelvben (1) látott napvilágot. $A z$ irányelv HFrEF-nek nevezte a szívelégtelenséget, ha a BKEF $\leq 40 \%$, HFpEF-nek, ha a BKEF $\geq 50 \%$, s a kettő között meghatározott egy „átmeneti zónát”, ahová azokat a betegeket sorolta, akik BKEF-je 40 és $50 \%$ között van. 
Ezt az „átmeneti zónát” nevezte el 2016-ban az Európai Kardiológus Társaság (ESC) által publikált szívelégtelenség irányelv (2) közepes ejekciós frakciójú szívelégtelenségnek (heart failure with mid-range ejection fraction - HFmrEF). Ez a szívelégtelenség-kategória egy meglehetősen heterogén betegcsoportot definiál. Ide tartoznak azok a betegek, akik valamikor a HFrEF-betegcsoportba tartoztak, de a megfelelő gyógyszeres és szükség szerint eszközös kezelés mellett javuló bal kamrai ejekciós frakciójuk miatt a HFmrEF-kategóriába kerültek. Ide tartoznak, azok a betegek, akik valamikor a HFpEF-kategóriába tartoztak, de a HFpEF-ben is mindig megfigyelhető szisztolés funkció károsodásuk progrediált, s így kerültek a HFmrEF-csoportba. Valamint ide tartoznak azok a betegek is hosszabb-rövidebb ideig, akiknek a szívelégtelenség diagnózisakor 40 és $50 \%$ közötti BKEF-jük van. Fontos azonban tudni, hogy a HFmrEF nem egy új betegségentitás, az ide tartozó betegek is kivétel nélkül dominálóan bal kamrai kontraktilitási zavar okozta, vagy dominálóan bal kamrai telődési zavar okozta szívelégtelenség patofiziológiát mutatnak. Az új szívelégtelenség-kategória (HFmrEF) bevezetésének célja csupán az volt, hogy felhívja a figyelmet ezekre a betegekre, akikről meglehetősen keveset tudunk, s kezelésüket illetően nagyon sokszor random soroljuk őket egyik vagy másik kategóriába (HFrEF, illetve HFpEF); illetve az, hogy inspirálja ennek a betegcsoportnak a megismerését célzó tudományos kutatásokat.

\section{A HFmrEF diagnózisa}

A jelenleg érvényes európai szívelégtelenség irányelv (2) alapján, míg a HFrEF diagnózisához a szívelégtelenségre jellemző tünetek és panaszok fennállása mellett a $40 \%$ alatti BKEF igazolása elegendő, a HFmrEF és a HFpEF diagnózisának felállítása a szívelégtelenségre jellemző tünetek és panaszok jelenlétén és a korábban már említett BKEF-kritériumokon túl további feltételeket igényel. Ilyen az emelkedett nátriuretikus peptidszint (NTproBNP >125 pg/ml; BNP > 35 pg/ml), illetve a strukturális szívbetegség (balkamra-hipertrófia, balpitvar-megnagyobbodás) és/vagy a bal kamra diasztolés diszfunkciójának igazolása (1. táblázat).

\section{A HFmrEF epidemiológiája}

Az elmúlt években számos nagy nemzetközi szívelégtelenség-regiszter vizsgálta a HFrEF, a HFpEF és a HFmrEF prevalenciáját a szívelégtelenség populáción belül (1. ábra).

A Get With the Guidelines - Heart Failure (GWTG-HF) (3) regiszterben a HFrEF-betegek aránya 47\%, a HFpEF-betegek aránya 39\%, a HFmrEF-betegek aránya $14 \%$ volt. Az Európai Hosszú távú Szívelégtelenség Regiszter (ESC Heart Failure Long-Term Registry)
1. TÁBLÁZAT. Diagnosztikus kritériumok HFrEF-ben, HFmrEF-ben és HFpEF-ben

HFrEF HFmrEF HFpEF

Szívelégtelenségre Szívelégtelenségre Szívelégtelenségre jellemző panaszok jellemző panaszok jellemző panaszok \pm tünetek $\quad \pm$ tünetek $\quad \pm$ tünetek

\begin{tabular}{l|l|l|l}
\hline LVEF $<40 \%$ & $40 \% \leq$ LVEF $<50 \%$ & LVEF $\geq 50 \%$
\end{tabular}

Emelkedett nátriu- Emelkedett nátriuretikus peptidszint retikus peptidszint

Strukturális szívbe- Strukturális szívbetegség és/vagy bal tegség és/vagy bal kamrai diasztolés kamrai diasztolés diszfunkció diszfunkció

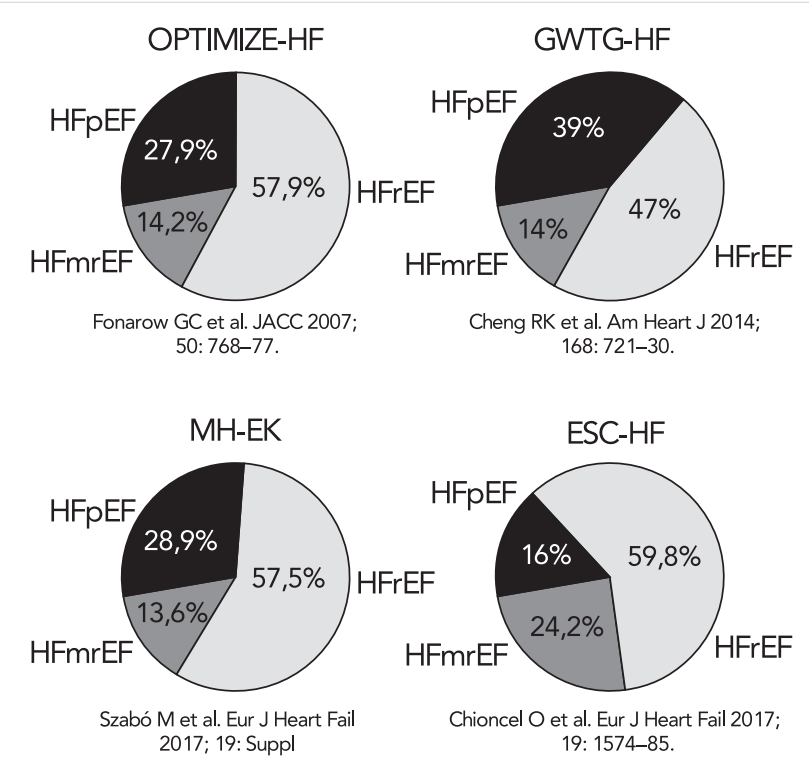

1. ÁBRA. A HFrEF, a HFpEF és a HFmrEF prevalenciája a teljes szívelégtelenség populáción belül

(4) 59,8\%-os (HFrEF), 16,0\%-os (HFpEF) és 24,2\%-os (HFmrEF) arányokat mutatott. Az OPTIMIZE-HF-regiszterben (5) a HFrEF-betegek aránya 57,9\%-nak, a HFpEF-betegeké 27,9\%-nak, míg a HFmrEF-betegeké 14,2\%-nak bizonyult. Az OPTIMIZE-HF-regiszter adataihoz hasonló eredményeket találtunk saját szívelégtelen beteganyagunkban (MH-EK, Kardiológiai Osztály, Szívelégtelenség Ambulancia) (6), ahol a teljes szívelégtelen betegpopuláció 57,5\%-át alkották a HFrEF, $28,9 \%$-át a HFpEF és 13,6\%-át a HFmrEF-betegek. Ezek az adatok is jól tükrözik, hogy a szívelégtelen betegpopuláción belül a HFmrEF-betegek egy jelentős arányt (15-25\%) képviselnek. Ez hazai viszonylatban akár 30-50 000 beteget jelenthet.

\section{A HFmrEF klinikai jellemzői}

Jól ismert, hogy a HFpEF-betegek idősebbek, magasabb közöttük a nők előfordulási aránya, s magasabb 
a különböző társbetegségek (pl. hipertónia, diabétesz, COPD, veseelégtelenség) gyakorisága, mint HFrEF-ben. A HFmrEF-betegek a klinikai jellemzők vonatkozásában intermedier pozíciót foglalnak el a HFrEF- és a HFpEF-betegek között $(3,5,7,8)$. Talán az egyetlen fontos kivételt az iszkémiás szívbetegség előfordulási aránya jelenti, ami a HFrEF- és a HFmrEF-csoportban egyaránt magas és nem különbözik egymástól szignifikánsan, ugyanakkor a HFpEF-csoportban lényegesen alacsonyabb $(3,7,8)$.

\section{A HFmrEF-betegek mortalitása és morbiditása}

A vizsgálatok többségében az összhalálozás és a kardiovaszkuláris halálozás szignifikánsan magasabb HFrEF-ben, mint HFpEF-ben, vagy HFmrEF-ben; míg a nem kardiovaszkuláris halálozás és a nem kardiovaszkuláris hospitalizáció HFpEF-ben és HFmrEF-ben magasabb a HFrEF-populációhoz képest $(3,7)$. Ebben a vonatkozásban a HFmrEF-betegcsoport a HFpEF-betegekhez hasonlít jobban. A szívelégtelenség miatti hospitalizáció a HFrEF-betegek körében szignifikánsan magasabb a HFpEF-betegekhez képest. Ebben a vonatkozásban a HFmrEF-betegek intermedier pozíciót foglalnak el $(3,7)$.

\section{A HFmrEF-betegek kezelése}

A HFmrEF-betegeket illetően a legfontosabb és mind a mai napig a leginkább megválaszolatlan kérdés, hogy hogyan kezeljük őket. Jelenleg mortalitás és morbiditás csökkentő evidenciákkal kizárólag a HFrEF-betegcsoportban rendelkezünk. Az ebben a betegcsoportban végzett vizsgálatok szinte kivétel nélkül $40 \%$ alatti BKEF-jú betegeket vizsgáltak. Így ezeket az evidenciákat nem tudjuk alkalmazni a HFmrEF-betegekre. A HFpEF-betegeket értékelő vizsgálatok 40\%, illetve $45 \%$ fölötti BKEF-jú betegeket soroltak be, így részben, vagy teljes mértékben magukba foglalták a HFmrEF-betegeket is. Azonban ezek közül a vizsgálatok közül egy sem igazolt mortalitáscsökkenést. S ezen túlmenően nem kellően alátámasztott, hogy a vizsgálatok ténylegesen HFpEF-, illetve HFmrEF-betegeket vizsgáltak. A besorolási kritériumok között ugyanis a vizsgálatok döntő többségében nem szerepeltek a nátriuretikus peptidszintek, s ugyancsak ritkán jelentett besorolási kritériumot a strukturális szívbetegség, illetve a diasztolés balkamra-diszfunkció igazolása. Jelenleg az evidenciákkal leginkább alátámasztott kezelési lehetőségnek a spironolakton alkalmazása tủnik. A spironolakton hatását HFpEF-ben, illetve HFmrEF-ben vizsgáló TOPCAT-tanulmány (9), ahol legalább opcionálisan szerepelt az emelkedett nátriuretikus peptidszint a besorolási kritériumok kö- zött, a teljes betegcsoportban a spironolakton szívelégtelenség miatti hospitalizációt csökkentő hatását igazolta a placebóhoz képest. Abban a betegcsoportban azonban, akik beválogatása az emelkedett nátriuretikus peptidszint alapján történt a spironolakton nemcsak a szívelégtelenség miatti hospitalizációt, hanem a vizsgálat primer végpontjának (kardiovaszkuláris halálozás+szívelégtelenség miatti hospitalizáció+abortált szívhalál) előfordulási valószínűségét is szignifikánsan csökkentette. Ezért jelenleg a spironolakton alkalmazása a 2013-es ACC/AHA szívelégtelenség irányelv 2017-es megújításában (10) már „BR" típusú evidencián alapuló II/b osztályú ajánlásként szerepel. A 2016-ban publikált ESC-irányelv (2) ennél konzervatívabban fogalmaz, s mind a HFpEF, mind a HFmrEF kezelését illetően a társbetegségek irányelveknek megfelelő kezelését javasolja, a pangásos tünetek és panaszok diuretikum kezeléssel történő enyhítése mellett.

A HFmrEF-kategória 2016-os bevezetését követően számos tanulmány alcsoport-analízise, számos metaanalízis, illetve több regiszter elemzése értékelte a különböző gyógyszerek és gyógyszercsoportok hatását ebben a betegcsoportban. A CHARM-program 2028 alacsony bal kamrai ejekciós frakciójú (BKEF $\leq 40 \%$ ) ACEi-intoleráns, 2548 szintén alacsony bal kamrai ejekciós frakciójú (BKEF $\leq 40 \%$ ), de ACEi-kezelésben részesülő és 3025 megtartott bal kamrai ejekcós frakciójú (BKEF $>40 \%$ ) betegben értékelte a candesartan hatását. A vizsgálat 2018-ban elvégzett alcsoport analízise (11) során a candesartan szignifikánsan csökkente a vizsgálat primer végpontja (kardiovaszkuláris halálozás és szívelégtelenség miatti hospitalizáció) kialakulásának valószínűségét mind a HFrEF-, mind a HFmrEF-betegcsoportban, de nem eredményezett hasonló kedvező hatást a HFpEF-csoportban. Cleland és munkatársai egy 2018-ban publikált metaanalízisben (12) a bétareceptor-blokkolók hatását értékelték. A metaanalízis a sinusritmusban lévő HFrEF- és HFmrEF-betegekben a bétareceptor-blokkolók szignifikáns kedvező hatását mutatták az összmortalitás és a kardiovaszkuláris mortalitás vonatkozásában. Ez a kedvező hatás azonban a HFpEF-betegek körében nem volt kimutatható. Hasonlóan a TOPCAT-vizsgálat alcsoport-analízise (13) is azt bizonyította, hogy míg a spironolakton kedvező hatása mind a vizsgálat primer végpontja (kardiovaszkuláris halálozás+szívelégtelenség miatti hospitalizáció+abortált szívhalál), mind a szívelégtelenség miatti hospitalizáció vonatkozásában $50 \%$ alatti BKEF esetén egyértelmű, addig ez a kedvező hatás az ejekciós frakció emelkedésével megszűnik. Mindezek alapján úgy tűnik, hogy a HFmrEF-betegcsoport a HFrEF-betegekhez hasonlóan reagál azokra a gyógyszerekre, illetve gyógyszercsoportokra, amelyek HFrEF-ben mortalitás illetve morbiditás csökkentő hatásúnak bizonyultak. 


\section{A HFmrEF-betegcsoport heterogenitása és az etiológiai diagnózis fontossága}

Jól ismert, hogy a HFpEF- és HFmrEF-betegcsoport lényegesen heterogénebb, mint a HFrEF-betegcsoport. (Minden bizonnyal ez az egyik - $s$ talán a legfontosabb - oka annak, hogy mind a mai napig nem rendelkezünk mortalitási evidencián alapuló kezelési lehetőséggel.) Ezért nagyon fontos a tünetek és a társbetegségek megfelelő kezelése mellett az etiológia (hipertónia, koronáriabetegség, diabétesz, hipertrófiás cardiomyopathia, amyloidosis, sarcoidosis, tárolási betegség pl. Fabry-kór stb.) szisztematikus keresése és megfelelő kezelése. A Fabry-kór enzimpótló kezelése, sarcoidosisban a szteroid alkalmazása, AL-amyloidosisban a megfelelő hematológiai kezelés jelentősen csökkentheti a betegek tüneteit. Az AL-amyloidosis mellett a másik gyakori kardiális amyloidosis típus a transthyretin amyloidosis tafamidis kezelése pedig már nemcsak a betegek tüneteit javítja, hanem egy közelmúltban publikált tanulmány (14) szerint a betegek mortalitását is szignifikánsan csökkenti. Ezért nagyon fontos a precíz etiológiai diagnózis mind HFpEF-, mind HFmrEF-betegekben.

\section{A HFmrEF-betegek hosszú távú ko̊vetése}

A HFmrEF- és HFpEF-betegek hosszú távú követése, szívelégtelenség ambulanciákon történő gondozása ugyanolyan fontosnak tủnik, mint a HFrEF-betegek esetében. A követés fontosságát hangsúlyozza az a tény is, hogy a szívelégtelen betegek BKEF-je a betegség lefolyása során jelentős mértékben változik. Egy közelmúltban publikált, közel 3500 beteg adatait értékelő vizsgálat (7) azt mutatta, hogy egyéves követés után a vizsgálat kezdetén HFmrEF-kategóriába tartozó betegek 44\%-a a HFpEF, $16 \%$-a pedig a HFrEF-kategóriába került. A vizsgálat kezdetén HFrEF-kategóriába tartozó betegek $22 \%$-a volt egy év után a HFmrEF-, illetve $18 \%$-a a HFpEF-kategóriában, míg a kezdetben HFpEF-betegek $10 \%$-ában volt olyan BKEF-csökkenés megfigyelhetö, hogy a HFmrEF (8\%), illetve a HFrEF (2\%) kategóriába kerültek. A változás követése azért is nagyon fontos, mert alapvetően meghatározza a betegek prognózisát. Ismert, hogy a HFrEF-betegek mortalitása valamivel magasabb, mint a HFpEF-, illetve a HFmrEF-betegek mortalitása. Az elöbb említett vizsgálat (7) azonban azt mutatta, hogy azoknak a HFpEF-, illetve HFmrEF-betegeknek a mortalitása, akik a követés során a HFrEF-kategóriába kerültek ugyanolyan rossz, vagy még rosszabb, mint azoké a betegeké, akik kezdetben a HFrEF-kategóriába tartoztak és ott is maradtak.

Jelenleg azt gondoljuk, hogy a HFrEF-betegeket függetlenül attól, hogy korábban milyen kategóriába tartoztak - a HFrEF-betegek kezelésére vonatkozó irányelvek szerint kell kezelnünk. Mint arról már a közlemény előző fejezetében szó volt, a HFmrEF-, illetve
HFpEF-betegek kezelésére vonatkozóan kevés evidenciánk van, fontos az etiológia és a társbetegségek keresése és megfelelő kezelése. A HFmrEF-betegek esetén a jelenleg rendelkezésünkre álló adatok alapján úgy túnik nem követünk el nagy hibát, ha a HFrEF-irányelveknek megfelelöen kezeljük öket, különösen azokat, akik HFrEF-re jellemző patofiziológiát mutatnak (dilatált bal kamrájuk van, iszkémiás etiológiájúak, férfiak stb.). Gyakran merül fel azonban a kérdés, hogy miIyen kezelési stratégiát alkalmazzunk azoknál a betegeknél, akik korábban a HFrEF-kategóriába tartoztak, de BKEF-jük a követés során $40 \%$ fölé emelkedik. A 2019-ben publikált TRED-HF-vizsgálat (15) eredményei alapján ezekben a betegekben folytatnunk kell a HFrEF-irányelveknek megfelelő kezelését, mivel a kezelés felfüggesztése sokszor a bal kamrai ejekciós frakció csökkenését, a bal kamrai végdiasztolés volumen növekedését, illetve az NTproBNP jelentős emelkedését, azaz a HFrEF relapszusát eredményezi.

\section{O̊sszefoglalás}

Bár sok még a megválaszolatlan kérdés a közepes ejekciós frakciójú szívelégtelenség kategória 2016-os bevezetése megsokszorozta az ezzel a betegcsoporttal foglalkozó vizsgálatokat. E vizsgálatok eredményei alapján tudjuk, hogy a HFmrEF-betegek a teljes szívelégtelenség populáció $15-20 \%$-át alkotják. Klinikai jellemzőiket tekintve intermedier csoportot jelentenek a HFrEF- és HFpEF-betegek között, bár az iszkémiás szívbetegség előfordulási gyakorisága a HFmrEF-betegekben a HFrEF-betegekéhez hasonlóan magas. A halálozás és a hospitalizáció vonatkozásában a HFmrEF-betegek valamivel közelebb állnak a HFpEF-betegekhez, mint a HFrEF-betegcsoporthoz. A szívelégtelenség miatti hospitalizáció vonatkozásában azonban a HFmrEF-betegek köztes pozíciót foglalnak el a HFrEF- és a HFpEFbetegek között.AHFmrEF-betegekaHFrEF-betegekhez hasonlóan kedvezően reagálnak a neurohormonális antagonista kezelésre. Tekintettel a HFmrEF- és a HFpEF-betegcsoport heterogenitására a társbetegségek megfelelő kezelése mellett alapvető fontosságú a precíz etiológiai diagnózis és a betegség hátterében álló kórkép megfelelő kezelése. Fontos a betegek követése, $s$ azokat a betegeket, akik korábban a HFmrEF-, illetve a HFpEF-betegcsoportba tartoztak, de a betegség lefolyása során a HFrEF-kategóriába kerültek, illetve azokat, akik a HFrEF-kategóriából kijavulva HFmrEF-, illetve HFpEF-betegekké váltak kezeljük egyaránt a HFrEF-evidenciáknak megfelelöen.

A HFmrEF-betegek kezelése mindezek ellenére mind a mai napig nem megoldott probléma. Számos gyógyszer és eszköz vizsgálata folyik, hogy tovább javíthassuk ennek a meglehetősen magas morbiditású és mortalitású, $s$ a szívelégtelen betegek jelentős tömegét képviselő betegcsoport prognózisát. 


\section{Irodalom}

1. Yancy CW, Jessup M, Bozkurt B, et al. 2013 ACCF/AHA guideline for the management of heart failure: a report of the American College of Cardiology Foundation/American Heart Association Task Force on practice guidelines. Circulation 2013; 128: 240-327. doi: 10.1161/CIR.0b013e31829e8776

2. Ponikowski P, Voors AA, Anker SD, et al. 2016 ESC Guidelines for the diagnosis and treatment of acute and chronic heart failure: The Task Force for the diagnosis and treatment of acute and chronic heart failure of the European Society of Cardiology (ESC) Developed with the special contribution of the Heart Failure Association (HFA) of the ESC. Eur Heart J 2016; 37: 2129-2200. doi: 10.1093/ eurheartj/ehw128

3. Cheng RK, Cox M, Neely ML, et al. Outcomes in patients with heart failure with preserved, borderline and reduced ejection fraction in the Medicare population. Am Heart J 2014; 168: 721-30. doi: 10.1016/j.ahj.2014.07.008

4. Chioncel O, Lainscak M, Seferovic PM, et al. Epidemiology and one-year outcome in patients with chronic heart failure and preserved, mid-range and reduced ejection fraction: an analysis of the ESC Heart Failure Long-Term Registry. Eur J Heart Fail 2017; 19: 1574-1585. doi: 10.1002/ejhf.813

5. Fonarow GC, Stough WG, Abraham WT, et al. Characteristics, treatments, and outcomes of patients with preserved systolic function hospitalized for heart failure: a report from the OPTIMIZE-HF Registry. J Am Coll Cardiol 2007; 50: 768-72. doi: 10.1016/j. jacc.2007.04.064

6. Szabó $M$, Dékány $M$, Muk $B$, Vágány $D$, Borsányi $T$, et al. The proportion of heart failure patients with reduced, mid-range and preserved ejection fraction in a real-life heart failure population. Eur $\mathrm{J}$ Heart Fail 2017; 19(1): 486.

7. Tsuji K, Sakata Y, Nochioka K, et al. Characterization of heart failure patients with mid-range left ventricular ejection fraction - a re- port from the CHART-2 Study. Eur J Heart Fail 2017; 19: 1258-1269. doi: 10.1002/ejhf.807

8. Rickenbacher P, Kaufmann BA, Maeder MT, et al. Heart failure with mid-range ejection fraction: a distinct clinical entity? Insight from the Trial of Intensified Versus Standard Mediacl Therapy in Elderly Patients With Congestive Heart Failure (TIME-CHF). Eur J Heart Fail 2017; 19: 1586-1596. doi: 10.1002/ejhf.798

9. Pitt B, Pfeffer MA, Assmann SA, et al. Spironolactone for Heart Failure with Preserved Ejection Fraction. N Eng J Med 2014; 370: 1383-1392. doi: 10.1056/NEJMoa1313731

10. Yancy CW, Jessup M, Bozkurt B, et al. 2017 ACC/AHA/HFSA Focused Update of the 2013 ACCF/AHA Guideline for the Management of Heart Failure. Circulation 2017; 136: e137-e161. doi.org/10.1161/ CIR.0000000000000509

11. Lund LH, Claggett B, Liu J, et al. Heart failure with mid-range ejection fraction in CHARM: characteristics, outcomes and effect of candesartan across the entire ejection fraction spectrum. Eur J Heart Fail 2018; 20: 1230-39. doi: 10.1002/ejhf.1149

12. Cleland JGF, Bunting KV, Flather MD, et al. Beta-blockers for heart failure with reduced, mid-range and preserved ejection fracton: an individual patient-level analysis of double-blind randomized trials. Eur Heart J 2018; 39: 26-35. doi: 10.1093/eurheartj/ehx564

13. Solomon SD, Claggett $B$, Lewis EF et al. Influence of ejection fraction on outcomes and efficacy of spironolactone in patients with heart failure with preserved ejection fraction. Eur J Heart Fail 2016; 37: 455-62. doi: 10.1093/eurheartj/ehv464

14. Maurer MS, Schwartz JH, Gundapaneni B, et al. Tafamidis Treatment for Patients with Transthyretin Amyloid Cardiomyopathy. New Eng J Med 2018; 379: 1007-1016. doi: 10.1056/NEJMoa1805689 15. Halliday BP, Wassall R, Lota AS, et al. Withdrawal of pharmacological treatment for heart failure in patients with recovered dilated cardiomyopathy (TRED-HF): an open-label, pilot, randomized trial. Lancet 2019; 393: 61-73. doi: 10.1016/S0140-6736(18)32484-X 